\title{
KORELASI ANTARA RELIGIUSITAS DAN APLIKASI KONSELING DENGAN PERILAKU PENYALAHGUNAAN NARKOBA SISWA SMA NEGERI DI MAKASSAR
}

\author{
Oleh: Wahyuni Ismail ${ }^{*}$
}

\begin{abstract}
This research aims at finding out the correlation between religious and counselling application and the trend of the students of SMAN Makassar to use drug. The data are collected by religious scale, counselling application scale, and the scale of drug abuse. The object of the research consists of 956 of XI year class of SMAN Makassar. The data analysis applies Multiple Regression technique. The findings shows that (1) there is a significant correlation between religious application and the use of drug of the students of SMAN Makassar, where $p=0,000$. (2) The study did not find any significant correlation between counselling application and drug abuse of the students of SMAN Makassar, where $p=0,055$.
\end{abstract}

KEYWORDS: Religiusitas, aplikasi konseling, perilaku narkoba

PERMASALAHAN mengenai narkoba merupakan masalah yang tak kunjung selesai. Penyalahgunaannya terbukti menimbulkan dampak negatif terhadap kehidupan manusia. Indonesia menambah 'daftar hitam' negara di dunia karena permasalahan narkoba. Munculnya fakta itu, Indonesia menjadi salah satu negara produsen narkotika, psikotropika dan zat adiktif. ${ }^{1}$ Dampak dari penyalahgunaan tersebut khususnya dialami oleh remaja. Seperti diketahui bahwa masa remaja merupakan salah satu periode perkembangan manusia yang paling banyak mengalami perubahan. Perubahan itu meliputi perubahan fisik, intelektual, moral, sosial, emosional dan religiusitas. Adanya keinginan untuk mencari identitas diri, rasa ingin tahu yang tinggi menyebabkan remaja berusaha untuk mencoba sesuatu hal baru. Terjadinya konflik batin antara ajaran agama dan norma masyarakat dengan keinginan yang tertanam dalam diri remaja sehingga secara psikologis menimbulkan kecemasan dan ketegangan dalam dirinya. Seiring perubahan tersebut maka akan menimbulkan banyak masalah mengkhawatirkan termasuk penyalahgunaan narkoba.

*Peraih Magister Sains dalam bidang Psikologi pada Program Pascasarjana UGM Yogyakarta tahun 2003 ini adalah dosen Fakultas Tarbiyah dan Keguruan UIN Alauddin Makassar. 
Salah satu penyebab timbulnya penyalahgunaan narkoba ialah faktor religiusitas dan faktor peranan guru bimbingan konseling. Melihat kasuskasus remaja yang terjadi dewasa ini diprediksikan adanya faktor yang mendasari dan berpengaruh kuat di lingkungan keluarga dan lingkungan sekolah.

Lembaga sekolah merupakan sistem sosial kecil tempat siswa mempelajari aturan moral, aturan sosial, sikap, dan cara bergaul dengan orang lain. Pengaruh sosialisasi di sekolah dihasilkan dari interaksi antar anak sekolah, para guru, staf sekolah, dan program kurikulum sekolah. Teman sebaya memungkinkan membawa pengaruh yang sangat penting pada pola sikap agresif dan prososial yang dipelajari siswa. Perilaku penyalahgunaan narkoba siswa lebih diarahkan pada pergaulan dengan teman sebayanya yang juga merupakan model nyata bagi suatu perilaku bentuk yang dapat dan mudah mereka tiru.

Remaja juga bisa mempelajari perilaku-perilaku prososial melalui media massa terutama televisi. Apa yang dipelajari remaja sebagian bergantung pada perkembangan kognitif mereka. Jika tidak diberikan pemahaman, anak dapat saja menyerap informasi yang ada tanpa mempertimbangkan efek yang ditimbulkan. Banyaknya masalah yang dihadapi di lingkungan keluarga, di lingkungan sekolah dan di lingkungan masyarakat membuat perilaku penyalahgunaan narkoba mereka meningkat.

Penerapan aplikasi konseling pada setiap lembaga pendidikan sekolah memiliki peranan penting. Eksistensinya sangat diperlukan guna membantu menghadapi berbagai macam persoalan yang dihadapi siswa khususnya persoalan mengenai perilaku penyalahgunaan narkoba. Sejauhmana aplikasi konseling memberikan kontribusi terhadap tindakan pencegahan perilaku penyalahgunaan narkoba siswa? Hal inilah merupakan fenomena menarik untuk diteliti.

Kondisi psikologis remaja ternyata mempunyai pengaruh yang cukup besar dalam kehidupan beragama mereka. Seperti yang dikemukakan Piaget bahwa remaja memiliki emosi yang sangat labil. Perkembangan kognitif remaja sudah berfungsi dengan baik sehingga memungkinkan mereka berpikir secara abstrak, kritik, dan teoritik. Remaja akan kritik terhadap hal apapun termasuk mengenai apa yang diyakininya dalam beragama. ${ }^{2}$ Thun memberikan suatu wawasan baru bagi pemahaman kehidupan beragama pada masa remaja. Sebagian dari mereka mengalami keraguan dan sebagian yang lain acuh terhadap agamanya. ${ }^{3}$

Pendapat tersebut didukung oleh Clark dengan menekankan bahwa konflik dan keragu-raguan beragama merupakan ciri kehidupan beragama pada masa remaja yang sangat menonjol. Remaja mulai mempertanyakan 
dengan sangat kritis tentang ajaran agama yang diterima begitu saja pada masa kanak-kanak. ${ }^{4}$ Paloutzian juga mengemukakan hal yang sama bahwa keterlibatan remaja dalam beragama sering tidak konsisten. Remaja kelihatannya menjadi sangat religius tetapi juga tidak religius. Suatu saat kelihatannya sangat intens melaksanakan ajaran agamanya, tetapi banyak pula penelitian yang menemukan bahwa remaja kurang begitu percaya terhadap agama. Mereka cenderung meragukan dan mempertanyakan agamanya. ${ }^{5}$

Berdasarkan fenomena itu maka lembaga pendidikan sekolah mempunyai peranan penting dalam membentuk kepribadian anak didik terutama aspek religiusitas. Substansial dari tujuan pendidikan itu mencerminkan hakekat pendidikan sebagai usaha membina dan mengembangkan semua potensi siswa seperti intelektual, keterampilan sosial, dan religiusitas. Proses pendidikan diharapkan mampu menghasilkan manusia yang sadar dengan potensinya serta mampu mengembangkannya. Aspek terpenting adalah dengan meningkatnya religiusitas siswa dan penerapan aplikasi konseling di lembaga pendidikan diharapkan siswa tidak terjerumus dalam kecenderungan perilaku penyalahgunaan narkoba.

Permasalahan yang menjadi fokus penelitian ini adalah:

1. Apakah ada korelasi antara tingkat religiusitas siswa dengan kecenderungan perilaku penyalahgunaan narkoba?

2. Apakah ada korelasi antara aplikasi konseling dengan kecenderungan perilaku penyalahgunaan narkoba?

Tujuan yang ingin dicapai dari penelitian ini adalah, untuk:

1. Menemukan korelasi tingkat religiusitas siswa terhadap kecenderungan perilaku penyalahgunaan nakoba.

2. Menemukan korelasi aplikasi konseling terhadap kecenderungan perilaku penyalahgunaan narkoba.

\section{TINJAUAN PUSTAKA}

\section{Religiusitas}

Religiusitas berasal dari bahasa Latin religio yang akar katanya adalah religure yang berarti mengikat. ${ }^{6}$ Ini mengandung makna bahwa dalam religi atau agama pada umumnya memiliki aturan-aturan dan kewajiban-kewajiban yang harus dipatuhi dan dilaksanakan oleh pemeluknya dan semua itu berfungsi untuk mengikat seseorang atau sekelompok orang dalam hubungan dengan Tuhan, sesama manusia dan alam sekitarnya. Mangunwijaya membedakan antara istilah religi atau agama dengan religiusitas. Jika agama menunjuk pada aspek-aspek formal yang berkaitan 
dengan aturan dan kewajiban, maka religiusitas menunjuk pada aspek religi yang telah dihayati oleh seseorang dalam hati. Berbagai pendapat di atas dapat ditarik kesimpulan bahwa religiusitas menunjuk pada tingkat keterikatan individu terhadap agamanya. Hal ini menunjukkan bahwa individu telah menghayati dan menginternalisasikan ajaran agamanya sehingga berpengaruh dalam segala tindakan dan pandangan hidupnya. ${ }^{7}$

Pembagian dimensi-dimensi religiusitas menurut Glock \& Stark terdiri dari lima dimensi, ${ }^{8}$ yaitu:

a. Dimensi keyakinan (the ideological dimension), tingkatan sejauh mana seseorang menerima dan mengakui hal-hal yang dogmatik dalam agamanya, misalnya keyakinan adanya sifat-sifat Tuhan, adanya malaikat, surga, para Nabi, dan sebagainya.

b. Dimensi peribadatan atau praktek agama (the ritualistic dimension) yaitu tingkatan sejauh mana seseorang menunaikan kewajiban-kewajiban ritual dalam agamanya, misalnya menunaikan shalat, zakat, puasa, haji, dan sebagainya.

c. Dimensi feeling atau penghayatan (the experiencal dimension) yaitu perasaan keagamaan yang pernah dialami dan dirasakan seperti merasa dekat dengan Tuhan, tentram saat berdoa, tersentuh mendengar ayat kitab suci, merasa takut berbuat dosa, merasa senang doanya dikabulkan, dan sebagainya.

d. Dimensi pengetahuan agama (the intellectual dimension) yaitu seberapa jauh seseorang mengetahui dan memahami ajaran-ajaran agamanya terutama yang ada dalam kitab suci, hadits, pengetahuan tentang fiqh dan sebagainya.

e. Dimensi effect atau pengamalan (the consequential dimension) yaitu sejauhmana implikasi ajaran agama mempengaruhi perilaku seseorang dalam kehidupan sosial, misalnya mendermakan harta untuk keagamaan dan sosial, menjenguk orang sakit, mempererat silaturahmi, dan sebagainya.

Pendapat itu sesuai dengan lima aspek dalam pelaksanaan ajaran agama Islam tentang aspek-aspek religiusitas yaitu aspek Iman sejajar dengan religious belief; aspek Islam sejajar dengan religious practice; aspek Ihsan sejajar dengan religious feeling; aspek Ilmu sejajar dengan religious knowledge; dan aspek Amal sejajar dengan religious effect (Subandi, 1988). ${ }^{9}$ Dapat dikatakan bahwa seseorang dikatakan religius jika orang mampu melaksanakan dimensi-dimensi religiusitas tersebut dalam perilaku dan kehidupannya. 


\section{Aplikasi Konseling}

American Personnel and Guidance Association (APGA) mendefinisikan konseling sebagai suatu hubungan antara seseorang yang terlatih secara profesional dan individu yang memerlukan bantuan yang berkaitan dengan kecemasan, konflik atau pengambilan keputusan. Devision 17 of the American Psychological Association (APA) merumuskan defenisi konseling sebagai bekerja dengan individu-individu atau kelompok-kelompok yang berkaitan dengan masalah-masalah pribadi, sosial, dan pendidikan. ${ }^{10}$ Konseling adalah suatu aktivitas pemberian nasehat antara konselor dan klien agar dapat memberikan pemecahan masalah.

Perilaku penyalahgunaan narkoba yang terjadi pada remaja sekolah jika tidak segera diatasi dengan cepat dan tepat maka dikhawatirkan akan berlanjut dan ditakutkan akan menjadi dasar kuat mereka sehingga melakukannya lagi pada masa yang akan datang. Oleh karena itu konselor harus melakukan usaha-usaha untuk menangani masalah perilaku penyalahgunaan narkoba dengan langkah-langkah seperti:

1. Langkah Identifkasi Kasus

2. Langkah Diagnosa

3. Langkah Prognosa Kasus

4. Langkah Pemberian Terapi

5. Langkah Evaluasi dan Follow up

Menurut Walgito pada dasarnya prosedur aplikasi konseling adalah:11

1. Fase persiapan, melalui kegiatan pengumpulan data, pengolahan data, pengambilan kesimpulan atas data yang ada, penentuan langkah-langkah yang akan dilakukan pada saat konseling.

2. Fase Konseling.

3. Fase Follow up.

\section{Perilaku Penyalahgunaan Narkoba}

Narkoba ialah zat yang menawarkan kenikmatan namun dibalik itu diam-diam bisa membunuh si pemakainya. Kalaulah selamat dari kematian efeknya bisa menimbulkan gangguan fungsi organ tubuh.12 Narkotika adalah bahan-bahan yang terutama memiliki dampak kerja pembiusan atau dapat menurunkan kesadaran, juga menimbulkan gejala-gejala fisik dan psikis jika dipakai tidak menurut ketentuan atau disalahgunakan (non medical purpose). Narkoba dikenal juga dengan istilah NAZA (Narkotika, Alkohol dan Zat Adiktif lainnya). Zat tersebut seringkali disalahgunakan sehingga menimbulkan ketagihan "addiction" sampai pada tahap ketergantungan "dependence'. Berdasarkan uraian tersebut disimpulkan bahwa 
yang dimaksud dengan penyalahgunaan narkoba pada penelitian ini adalah pengguanaan narkoba diluar ketentuan medis atau tanpa melalui aturan dan resep dokter. Hadjam dan Fuhrmann mengemukakan bahwa proses keterlibatan seseorang dalam penyalah-gunaan narkoba melalui beberapa tahap, yaitu: ${ }^{13}$

1. Kecenderungan untuk berkenalan dengan narkoba ialah menunjuk pada besarnya minat individu terhadap informasi tentang penyalahgunaan narkoba.

2. Kecenderungan untuk coba-coba, ialah menunjuk pada besarnya minat individu mencoba untuk pertama kali setelah memperoleh informasi baik karena dorongan curiosity atau desakan dari lingkungan.

3. Kecenderungan untuk menggunakan narkoba secara iseng yaitu besarnya minat individu menggunakan narkoba secara berkala khususnya pada peristiwa khusus seperti saat pesta dan berkumpul dengan temannya.

4. Kecenderungan untuk menggunakan narkoba secara tetap dan teratur tanpa adanya ketergantungan, ialah besarnya minat individu untuk memakai narkoba secara tetap dan teratur.

5. Kecenderungan menggunakan narkoba secara tetap karena ketergantungan baik ketergantungan fisik maupun psikis.

6. Kecenderungan untuk menghentikan penggunaan narkoba dengan kegiatan terapi, ialah besarnya minat individu untuk menghentikan perilaku penyalahgunaan narkoba.

Perilaku penyalahgunaan narkoba dalam penelitian ini menekankan pada proses keterlibatan remaja SMU sebagaimana yang dikemukakan oleh Hadjam dan Fuhrmann. Intensi atau kecenderungan merupakan indikasi besarnya usaha individu dalam merencanakan dan mencoba melakukan suatu perilaku. Terbentuknya perilaku ditentukan oleh intensitas tindakan seseorang.

\section{METODE PENELITIAN}

\section{Variabel Penelitian}

Variabel yang digunakan dalam penelitian ini adalah:

1. Variabel Prediktor yaitu Religiusitas dan Aplikasi Konseling.

2. Variabel Kriterium yaitu Kecenderungan Perilaku Penyalahgunaan Narkoba.

\section{Definisi Operasional Variabel Penelitian}

1. Religiusitas dalam penelitian ini adalah menunjuk pada kadar keterikatan siswa terhadap ajaran agamanya. Hal ini menunjukkan bahwa siswa 
tersebut telah menginternalisasikan dan menghayati ajaran agamanya sehingga berpengaruh pada perilaku dan pandangan hidupnya.

2. Aplikasi Konseling dalam penelitian ini adalah usaha-usaha yang dilakukan guru konselor di sekolah untuk menangani masalah kecenderungan perilaku penyalahgunaan narkoba.

3. Kecenderungan Perilaku Penyalahgunaan Narkoba adalah besarnya minat remaja untuk menggunakan narkoba diluar ketentuan medis. Tingginya kecenderungan atau intensi untuk menyalahgunakan narkoba.

\section{Populasi dan Sampel Penelitian}

Populasi dalam penelitian ini adalah siswa yang menempuh pendidikan di SMAN dengan spesifikasi untuk kelas 2. Adapun alasan dipilihnya siswa kelas 2 ini adalah karena mereka telah mampu melakukan suatu analisis mengenai pelajaran atau memahami situasi lingkungan yang ada di sekolahnya. Karena dalam penelitian ini sampelnya merupakan siswa-siswa yang tersedia dalam unit populasi, maka teknik pengambilan sampelnya ditetapkan secara purpossive cluster random sampling yaitu memilih sampel berdasarkan tingkat kelas tertentu kemudian setiap SMAN diklasifikasikan berdasar pada kategori sekolah kemudian siswa pada tiap SMAN dalam kelas dipilih secara acak. Subjek yang menjadi sampel dalam penelitian adalah siswa atau santri yang memiliki ciri-ciri a) berstatus sebagai siswa SMAN di Makassar, b) duduk di kelas 2, c) berusia antara 1618 tahun, dalam hal ini usia bukan batasan mutlak karena mungkin ada subjek yang umurnya 14-15 tahun dan duduk di kelas dua maka berpeluang juga dijadikan sampel, d) beragama Islam.

Sampel penelitian dilakukan berdasarkan penentuan lokasi $14 \mathrm{Ke}-$ camatan yang ada di Makassar yaitu Kecamatan Biringkanaya, Bontoala, Makassar, Mamajang, Manggala, Mariso, Panakkukang, Rappocini, Tallo, Tamalanrea, Tamalate, Ujung Pandang, Ujung Tanah dan Wajo. ${ }^{14}$ Kemudian diambil perwakilan satu SMAN di 7 Kecamatan, adapun rinciannya sebagai berikut:

\begin{tabular}{|c|c|c|c|c|c|}
\hline No & Kecamatan & Sekolah & IPA (Gugur) & IPS (Gugur) & Total \\
\hline 1 & Makassar & SMAN 1 & $121(7)$ & $53(5)$ & 174 \\
\hline 2 & Panakkukang & SMAN 5 & $71(1)$ & $38(1)$ & 109 \\
\hline 3 & Biringkanaya & SMAN 7 & 78 & $46(1)$ & 124 \\
\hline 4 & Tamalate & SMAN 8 & $62(3)$ & $37(1)$ & 99 \\
\hline 5 & Rappocini & SMAN 9 & $125(2)$ & 40 & 165 \\
\hline 6 & Mariso & SMAN 14 & 88 & 55 & 143 \\
\hline 7 & Ujung Pandang & SMAN 16 & $77(2)$ & 65 & 142 \\
\hline 8 & Jumlah Sampel & & $624(15)$ & $335(8)$ & 956 \\
\hline
\end{tabular}


Sampel penelitian yang dinggap gugur karena tidak lengkap dalam memberikan jawaban pada setiap variabel penelitian. Jumlah keseluruhannya sebanyak 23 siswa.

\section{Metode Pengumpulan Data}

Pengumpulan data penelitian ini menggunakan metode angket. Tingkat religiusitas diukur dengan menggunakan angket yang disusun oleh Afiatin dengan beberapa modifikasi. ${ }^{15}$ Adapun indikator religiusitas ini terdiri dari a) dimensi keyakinan atau ideological involvement, b) dimensi peribadatan atau ritual involvement, c) dimensi penghayatan atau experiencal involvement, d) dimensi pengetahuan agama atau intellectual involvement, e) dimensi pengamalan atau consequential involvement. Data yang diambil berdasarkan teori yang dikemukakan oleh Glock dan Strak. ${ }^{16}$

Angket aplikasi konseling berdasarkan pada bentuk-bentuk penanganan masalah dengan cara: a) identifikasi kasus, b) diagnosa, c) prognosa, d) pemberian terapi, dan e) evaluasi dan follow up.

Angket kecenderungan perilaku penyalahgunaan narkoba berdasarkan teori Hadjam dan Fuhrmann bahwa proses keterlibatan seseorang dalam penyalahgunaan narkoba melalui beberapa tahap, yaitu: a) kecenderungan untuk berkenalan dengan narkoba; b) kecenderungan untuk cobacoba; c) kecenderungan untuk mnggunakan narkoba secara iseng; d) kecenderungan untuk menggunakan narkoba secara tetap dan teratur tanpa adanya ketergantungan; e) kecenderungan menggunakan narkoba secara tetap karena ketergantungan baik fisik maupun psikis; f) kecenderungan untuk menghentikan penggunaan narkoba dengan kegiatan terapi. ${ }^{17}$ Angket ini yang disusun oleh Prasetya dengan modifikasi peneliti.

\section{Teknik Analisis Data}

Penelitian ini menggunakan pendekatan analisis statistik dalam menganalisis data yang terkumpul. Pemilihan model statistik yang akan digunakan haruslah disesuaikan dengan rancangan penelitian yang telah ditetapkan. Analisis data menggunakan Analisis Regresi Ganda melalui Program SPSS for Windows 17.

\section{HASIL PENELITIAN DAN PEMBAHASAN}

\section{Hasil Uji Pra Syarat Hipotesis}

1) Uji Normalitas Sebaran dengan menggunakan One-Sample KolmogorovSmirnov Test dapat dilihat tabel berikut ini: 


\begin{tabular}{|c|c|c|c|c|}
\hline Variabel & Mean & Sd.Deviasi & K-SZ & Keterangan \\
\hline Religiusitas & 119.684 & 7.852 & 1.831 & Normal \\
\hline Aplikasi Konseling & 120.588 & 16.144 & 4.851 & Normal \\
\hline $\begin{array}{c}\text { Perilaku Penyalahgunaan } \\
\text { Narkoba }\end{array}$ & 102.507 & 9.623 & 2.137 & Normal \\
\hline
\end{tabular}

Nilai Koefisien K-SZ = 1.831 terhadap variabel Religiusitas, K-SZ = 4.851 variabel Aplikasi Konseling, dan K-SZ = 2.137 variabel penyalahgunaan narkoba nilai menunjukkan bahwa sebaran data pada setiap variabel adalah normal.

2) Uji Linieritas, kaidah yang digunakan adalah jika nilai $p>0.05$ maka hubungan antara kedua variabel adalah linier.

\begin{tabular}{|c|c|c|c|}
\hline Korelasi Antar Variabel & F & Sig & Keterangan \\
\hline Religiusitas $\rightarrow$ Narkoba & 1.236 & 0.136 & Linier \\
\hline Aplikasi Konseling $\rightarrow$ Narkoba & 1.563 & 0.002 & T Linier \\
\hline
\end{tabular}

\section{Uji Hasil Hipotesis}

Hasil Uji Hipotesis 1.

Religiusitas dengan Perilaku Penyalahgunaan Narkoba

\begin{tabular}{|c|c|c|c|c|c|}
\hline Variabel & B & Std. Error & Beta & T & Sig \\
\hline Religiusitas & 0.335 & 0.040 & 0.274 & 8.438 & 0.000 \\
\hline
\end{tabular}

Berdasarkan hasil analisis data, dapat dikatakan bahwa terdapat korelasi yang signifikan antara religiusitas dengan perilaku penyalahgunaan narkoba pada remaja SMAN dengan nilai $\mathrm{p}=0.000$ (kaidah yang digunakan adalah jika nilai $\mathrm{p}<0.05$ maka korelasi signifikan). Peneliti mengatakan bahwa hipotesis pertama diterima karena berpedoman pada analisis data terbukti kebenarannya bahwa tingkat religiusitas menunjukkan korelasi yang positif yaitu semakin tinggi religiusitas remaja maka semakin rendah tingkat perilaku penyalahgunaan narkoba dan sebaliknya.

Hal tersebut sangat memungkinkan terjadi karena para remaja atau siswa selalu mendapatkan pemahaman, teladan, ataupun implementasi ajaran religuisitasnya di lembaga pendidikan formal yaitu di sekolah masing-masing siswa. Salah satu mata pelajaran mereka yaitu Pendidikan Agama Islam menjadi kurikulum yang wajib meskipun durasi pada perminggu masih kurang.

Selain itu para siswa juga mendapatkan pembelajaran dari lingkungan keluarga bahkan di lingkungan masyarakat mereka. Penanaman nilai keagamaan yang diberikan sejak dini di lingkungan keluarga akan memperkuat filter para siswa untuk tidak mengenal, mengetahui, merasakan bahkan ketagihan terhadap narkoba. Karena dalam agama Islam sudah 
ditekankan mengenai hukum mengkomsumsi narkoba. Belum lagi pemahaman efek yang ditimbulkan narkoba yaitu sakit, penjara atau maut.

Hasil Uji Hipotesis 2.

Aplikasi Konseling terhadap Penyalahgunaan Narkoba

\begin{tabular}{|c|c|c|c|c|c|}
\hline Variabel & B & Std, Error & Beta & T & Sig \\
\hline Konseling & -0.37 & 0.019 & $-0,62$ & -1.920 & 0.055 \\
\hline
\end{tabular}

Berpedoman hasil analisis di atas dapat diketahui bahwa tidak ada korelasi aplikasi konseling dengan perilaku penyalahgunaan narkoba pada remaja SMAN dengan nilai $\mathrm{p}=0.055$ (kaidah yang digunakan yaitu jika nilai $p>0.05$ maka korelasi antar variabel tidak signifikan).

Fenomena yang ditemukan di atas berdasarkan penelitian yang telah dilakukan yang mendeskripsikan bahwa tidak ada korelasi antara aplikasi konseling terhadap perilaku penyalahgunaan narkoba mengindikasikan bahwa aplikasi konseling di setiap SMAN di Makassar jarang atau bahkan tidak terlaksana dengan baik. Hal ini disebabkan karena kurangnya sosialisasi tentang keberadaan bimbingan dan konseling di setiap lembaga pendidikan, para siswa atau remaja sering menganggap bahwa orang yang berurusan dengan guru BK di sekolah adalah teman-teman mereka yang memiliki masalah psikologis dan pengetahuan siswa minim terhadap fasefase konseling yang telah mereka dapatkan.

Peranan guru Bimbingan dan Konseling memegang peranan yang sangat penting. Sebagaimana diketahui bahwa perilaku para remaja pada masa ini sering berubah-ubah terutama mengenai sesuatu hal yang baru bagi mereka. Informasi yang mereka dapatkan dari berbagai media massa, teman, dan masyarakat sekitarnya tentang narkoba yang kurang akurat membuat mereka ingin mengetahui bahkan mencoba apa itu sebenarnya narkoba. Di sinilah di tuntut partisipasi aktif dari guru Bimbingan Konseling untuk menyampaikan informasi ataupun memberikan bentukbentuk aplikasi dari proses konseling terutama bagi siswa yang sudah terlanjur memakai bahkan ketergantungan terhadap narkoba tersebut. Bagaimanapun tindakan preventif harus diimplementasikan daripada tindakan kuratif terhadap kecenderungan perilaku penyalahgunaan narkoba di kalangan remaja di setiap sekolah-sekolah.

\section{KESIMPULAN DAN SARAN}

Berdasarkan hasil penelitian dapat dirumuskan kesimpulan, yaitu :

1. Ditemukan korelasi yang sangat signifikan antara religiusitas dengan kecenderungan perilaku penyalahgunaan narkoba pada remaja SMAN di Makassar dengan harga $p=0.000$ dimana $p<0.05$. 
2. Tidak ditemukan korelasi yang signifikan aplikasi konseling terhadap perilaku penyalahgunaan narkoba pada remaja SMAN di Makassar dengan nilai $\mathrm{p}=0.55$ dimana $\mathrm{p}>0.05$.

Berlandaskan hasil penelitian ini maka diharapkan kepada:

1. Lembaga pendidikan dapat lebih meningkatkan proses pembelajaran tentang efek yang ditimbulkan dengan mengkonsumsi narkoba dan membentenginya dengan cara pendekatan religiusitas yang diajarkan di sekolah.

2. Guru Bimbingan Konseling memberikan informasi dan sosialisasi kepada siswa bahwa aplikasi konseling itu hendaknya diketahui bahkan dilaksanakan khususnya terhadap siswa yang memiliki masalah narkoba. Demikian pula Guru PAI bisa memberikan pengarahan bahwa dasar agama yang remaja miliki merupakan modal dasar bagi mereka agar bisa mengantisipasi terlibat pada perilaku penyalahgunaan narkoba.

3. Peneliti selanjutnya hendaknya tidak membatasi sampel penelitian hanya pada Sekolah Menengah Umum Negeri saja, akan tetapi sampel diperluas sehingga hasil yang diperoleh dapat digeneralisasikan.

\section{CATATAN AKHIR}

1. Seputar Indonesia, Berantas Penyalahgunaan Narkoba, Koran Harian. 15 April 2008.

2. E-Psikologi. com. 2000. Remaja dan Agama. http://www.yahoo.com.

3. D.N. Wullf, Psychology of Religion: Classic and Contemporary View, New York: Willy, 1991, h. 24.

4. W.H. Clark, The Psychology of Religion, New York: The McMillan Company, 1958, h. 35.

5. R.F. Paloutzian, Purpose in Life and Value Changes Following Confertion, Juornal of Personality and Social Psychology, Vol. 41. No. 6. P. 1153-1160, 1984, h. 56.

6. E-Psikologi.com., op.cit.

7. Y.B. Mangunwijaya, Sastra dan Religiusitas, Jakarta: Sinar Harapan, 1982, h. 67.

8. Subandi, Hubungan antara tingkat Relgiusitas dengan Kecemasan Pada Remaja, Laporan Penelitian, Yogyakarta: Fakultas Psikologi UGM, 1988, h. 65 dan E-Psikologi.com. op.cit.

9. Subandi, Ibid, h. 67.

10. H.B. Adz-Dzaky, Konseling dan Psikoterapi Islam, Penerapan Metode Sufistik, Yogyakarta: Fajar Pustaka Baru, 2002, h. 179-180.

11. Bimo Walgito, Bimbingan dan Konseling: Studi dan Karir, Yogyakarta: Andi Offset, 2005, 78.

12. Seputar Indonesia, Drug, Seks dan Disfungsi Ereksi, Koran Harian, 19 Maret 2008. 
13. B.S. Fuhrmann, Adolescence-adolescence, Second Edition, Illinois: Scott, Foresman and Company, 1990, h. 156 dan N. Hadjam, Koordinasi dalam Rangka Penyuluhan Penanggulangan Penyalahgunaan Narkoba Proyek Pembinaan Kesejahteraan Sosial Tahun Anggaran 1987/1988, Laporan Pelaksanaan, Yogyakarta: Biro Bina Sosial, 1988, h. 54.

14. (http//desa-pesisir.pend.depdagri.co.id).

15. T. Afiatin, Religiusitas Remaja: Studi tentang Kehidupan Beragama Remaja di Daerah Istimewa Yogyakarta, Laporan penelitian, Yogyakarta: Fak. Psikologi UGM, 1997, h. 70.

16. T. Afiatin, ibid., dan E-psikologi.com, 2000, op.cit.

17. N. Hadjam, op.cit., h. 68 dan B.S. Fuhrmann, op.cit., h. 167.

\section{DAFTAR PUSTAKA}

Adz-Dzaky, H.B., Konseling dan Psikoterapi Islam, Penerapan Metode Sufistik, Yogyakarta: Fajar Pustaka Baru, 2002.

Afiatin, T., Religiusitas Remaja: Studi tentang Kehidupan Beragama Remaja di Daerah Istimewa Yogyakarta, Laporan penelitian, Yogyakarta: Fak. Psikologi UGM, 1997.

Clark, W.H., The Psychology of Religion, New York: Tha McMillan Company, 1958.

Corey, G., Teori dan Praktek Konseling dan Psikoterapi, Edisi Kedua, Bandung: PT Refika Aditama, 2007.

Ensiklopedia Islam, Jakarta: Internusa, 1999.

E-Psikologi.com., Remaja dan Agama. http:/ / www.Yahoo.com., 2000

Fuhrmann, B.S., Adolescence-adolescence, Second Edition, Illinois: Scott, Foresman and Company, 1990.

Hadjam, N., Koordinasi dalam Rangka Penyuluhan Penanggulangan Penyalahgunaan Narkoba Proyek Pembinaan Kesejahteraan Sosial Tahun Anggaran 1987/1988, Laporan Pelaksanaan, Yogyakarta: Biro Bina Sosial, 1988.

Hallahmi, B. and M. Argyle, The Psychology of Religiuos Behavior, Belief and Experience, London and New York: Rout Ledge, 1997.

http// desa-pesisir.pend.depdagri.co.id

Howard, A., Konseling dan Psikoterapi, Cara Filsafat (dari Pythagoras hingga Posmodernisme), Jakarta: Teraju, 2005.

Jalaluddin, Psikologi Agama, Jakarta: PT. Raja Grafindo Persada, 1997.

Mangunwijaya, Y.B., Sastra dan Religiusitas, Jakarta: Sinar Harapan, 1982.

Muzzafar, C., Accomodation and Acceptence of Non Muslim Communities, Within the Malaysian Political System, The Role of Islam, The American, 0155.13, 1, 28-41, 1996.

Najati, M.U., AlQuran dan Ilmu Jiwa, Bandung: Pustaka, 1985.

Nashori, F., Manusia Sebagai Homoreligius, Psikologika. N. 3, 3-5, 1997.

Paloutzian, R.F., Purpose in Life and Value Changes Following Confertion, Juornal of Personality and Social Psychology, Vol. 41. No. 6. P. 1153-1160, 1984.

Travelga, S., Penyalahgunaan Narkoba di Kalangan Generasi Muda, Jurnal Psikologi, Vol.5, No.1, Maret, Bandung: Fakultas Psikologi Unpad, 2000. 
Seputar Indonesia, Berantas Penyalahgunaan Narkoba, Koran Harian. 15 April 2008.

, Drug, Seks dan Disfungsi Ereksi, Koran Harian, 19 Maret 2008.

Spilka, B., R.W. Hood and R.L. Gorsuch, The Psychology of Religion: An Empirical Approach, New Jersey: Engelwood Cliff, Prentice Hall, 1985.

Subandi, Hubungan antara tingkat Relgiusitas dengan Kecemasan Pada Remaja Laporan Penelitian, Yogyakarta: Fakultas Psikologi UGM, 1988.

Tim Dosen, PBB FIP UNY., Bimbingan dan Konseling Sekolah Menengah, Yogyakarta: UNY, 1993.

Walgito, Bimo, Bimbingan dan Konseling (Studi dan Karir), Yogyakarta: Andi Offset, 2005.

Wicaksana, I., Stress, Depresi dan Penyalahgunaan Narkotika di Kalangan Kaum Muda, Yogyakarta: Sarasehan, 1993.

Wolters, C.A., Self Regulated Learning and College Students Regulation of Motivation, Journal of Educational Psychology, 90,2, 224-235, 1998.

Wullf, D.N., Psychology of Religion: Classic and Contemporary View, New York: Willy, 1991. 